\title{
Expansion of Rice for Job Initiative Programme: Implications for Household Food Security in Lagos State Nigeria
}

\author{
Ambali O.I. ${ }^{1, *}$, Adewuyi S.A. ${ }^{2}$, Babayanju S. O. ${ }^{1}$, Ibrahim S. B. ${ }^{2}$ \\ ${ }^{1}$ Department of Agricultural Economics and Farm Management, Olabisi Onabanjo University, Yewa Campus, Nigeria \\ ${ }^{2}$ Department of Agricultural Economics and Farm Management, Federal University of Agriculture Abeokuta, Nigeria
}

Copyright $(\underset{0}{2015}$ Horizon Research Publishing All rights reserved.

\begin{abstract}
Nigeria is listed among the 55 Low Income Food Deficit (LIFD) countries due to the high prevalence of undernourishment especially among agricultural households. Against the background that most indirect measures of food insecurity such as dietary intake, anthropometric measure, income and total expenditure fail to address the severity of food insecurity, this study applied the experienced-based method. This study assessed the potential impact of Expansion of Rice for Job Initiative Programme on household food security in Lagos State Nigeria using the USDA method and logit model. The study found relatively high incidence of food insecurity (52.5\%) among the rice farm households. The logit results revealed that household food security has a 50/50 chance of improvement with additional level of education, increase in farm size and household income. Food insecurity however increases with additional family member. Inadequate rainfall, lack of technical knowledge and low extension services are the highly ranked constraints of rice production in the study area. Large family size reduces the consumption of nutritious food; low extension services reduce the adoption of new agricultural technologies and inadequate technical know-how causes inefficiency. These have effects on household income and increase the severity of food insecurity. Educating farm household head on family size control and adequate training on improved farm techniques are recommended. Household heads should be educated on the nutritional importance of food items. Irrigation facilities are important to enhance productivity. Diversification of household income will ensure regular income for the households. The impact of this empowerment initiative on household food security will be more if the rice farmers (beneficiaries) can be provided with improved production technologies and incentives.
\end{abstract}

Keywords Rice, Food Insecurity, Household Income, Extension Services, Beneficiaries, Lagos State, Nigeria

\section{Introduction}

Food is a basic necessity of life. The importance of food is significant at the household level because it is a basic means of sustainability [1]. Quality intake of adequate nutrient is important for healthy and productive life. Many countries are experiencing food insecurity because food supplies are inadequate to maintain their citizens' per capita consumption. Roughly $50 \%$ of the world population depends on rice as a staple food, with $95 \%$ of the world's rice output consumed by humans, but its domestic production has never been able to meet the demand [2]. According to [3], the demand and supply gap in rice production is widening, resulting in huge import bill on rice especially in Africa. Rice is ranked first in calorie among staple food because it contains all the essential nutrients require for healthy life.

Food insecurity is a global challenge. The number of undernourished people worldwide increased from 840 million in 2006 to 923 million in 2007 [4]. FAO [4] asserts that soaring food and fertilizer prices compound the problem as food prices increased by 52\% between 2007 and 2008 while fertilizer prices nearly doubled over this period. An estimated 925 million people were undernourished in 2010, out of which about 900 million people live in developing countries [5]. Also, more than $70 \%$ of the undernourished people live in rural areas and depend directly or indirectly on agriculture [6]. Sub-Saharan Africa (SSA) has the highest incidence of undernourishment in the world, with over $40 \%$ undernourished people [7]. SSA is also the most vulnerable region to food insecurity with high dependence on food import and food assistance. Nigeria has the highest number of undernourished people in Africa due to its expanding population.

Thirty nine (39) countries were in serious food emergency situations in 2006 and required external help to tackle food insecurity; 25 countries out of these 39 are located in Africa. Despite Africa resource endowments, the number of food emergencies increased from 1980s; tripled over two decades [8]. Every year, 6 million children die from malnutrition; 1 
billion people in the world live on less than US \$1 a day, 2.7 billion struggles for survival on less than US \$2 while over 800 million go to bed hungry, including 300 million children [9]. Undernourishment is a tragedy for many households in Africa.

The most referenced definition of food security is given by WFP in 1996 and modified to include "social access" by FAO in 2002. Food security exists "when all people, at all times, have physical, economic and social access to sufficient, safe and nutritious food to meet their dietary needs and food preferences for a healthy and active life" $[9,10]$. The argument in recent time is that availability does not assure access and enough calories do not assure a healthy and nutritional diet.

This definition identified four components of food security: availability, access, utilization and stability. Availability is necessary but not sufficient for access as access is not also sufficient for utilization. Food security is a measure of household or individual welfare [11]. Food access is multi-dimensional as food security itself making it very difficult to measure. According to [12], analysts and practitioners spent a lot of time seeking for ways to measure the "access" dimensions of food security with little success. These four components, though difficult to measure, are important for assured food security.

Rising food price impacts negatively on household income and welfare. In addition, hunger and malnutrition impacts negatively on labour productivity, health and education and cause low economic growth. Nigeria GDP increased from US \$25 billion in 1995 to US \$200 billion in 2010. The GNI also increased from US $\$ 200$ to US $\$ 1,200$ over the same period [13]. This shows a good economic indicator for Nigeria at national level. Does this aggregate income translate to economic emancipation, especially among the rural farm households? Available statistics shows that many Nigerians are food insecure. Accordingly, [13] shows that over fifteen years, the per capita food supply in terms of food quantity ( $\mathrm{Kcal} /$ capita/day) increased from 2,556 in 1996 to 2,724 in 2011. On the other hand, statistics shows high prevalence of undernourishment. For over thirteen years, the prevalence of under nutrition dropped marginally from $10 \%$ between $1991-2001$, to $7 \%$ between 2004-2009 and 9\% between 2010-2012 [13]. The impact of national income on household welfare in Nigeria remains miserable.

Lagos State, despite her high industrialized status with a population density of about 5,000 per $\mathrm{km}^{2}$ and pressure on land for non-agricultural purposes, intensified productive farming activities in the areas where it has comparative ecological and socio-economic advantages. The domestic food supply is very small when compared with the total food consumption. The State is therefore poised to increasing this with her various projects and programmes. Some of the food security impact programmes intensified in the last few years included: 5-Year Strategic Food Security Plan, Strategic Food Reserve beginning with a modern High Quality Cassava factory at Araga in Epe, Expansion of Rice for Job
Initiative Programme, Agric Youth Empowerment Scheme (AGRIC-YES) and improvement beyond 4-Course at Araga, Epe.

${ }^{1}$ The rice for jobs programme was launched in 2008 to create jobs for unemployed youths. The primary aim is to strengthen local capacity for rice production, with a production target of 1,600 tonnes of paddy per annum and to facilitate access to rice processing equipment. The programme is said to have positively impacted 180 farmers within the last three years. The number of beneficiaries is increasing every day due to the positive impact of this programme. These farmers have been producing an average of 180 tons of rice per annum, which is still far off from the consumption target of 540,000 tonnes per annum for Lagos alone.

This Programme has re-introduced modern rice farming from less than 50 hectares annually to over 250 hectares at Itoikin, Epe and Itoga in Badagry. Yield is reported to have improved following the implementation of this programme. Thirty-five (35) hectares of modern irrigation facilities are under cultivation at Itoga. Rice mills are established to address the food security challenges of the State. Nigeria is currently importing about 1 million metric tonnes of rice and Lagos and parts of the Southwest account for close to 500,000 metric tonnes. This is set to change with the Lagos State government's commitment to boost rice production. The rice mill located at Imota creates jobs and businesses for transporters, farmers, and others in the rice value chain.

Food insecurity remains a miserable picture despite the enormous sum of public funds invested so far. Ajani [14] stressed that food insecurity is generally associated with fluctuation in household production and food prices. These fluctuations in turn, lead directly to variation in real income, which then affects household income and economic access. Therefore, reducing household food insecurity entails increasing access to productive resources. The prevalence of food insecurity is high in rural Nigeria despite the fact that bulk of agricultural activities takes place in these areas [15]. The concept of food security ensures that households are able to obtain adequate food either through home production or through purchase. However, farmers are not supported with necessary incentives which explain the reason for low productivity and low farm income.

Non-empowerment is part of food insecurity problem in Nigeria. Nigeria is endowed with physical and human resources and fertile land to produce enough rice for the entire population and even export the surplus. However, rice has been imported to support the insufficient domestic production. Many farm households in Nigeria still operate at subsistence level [16]. Also, most of the inhabitants of Lagos State engaged in activities outside the agricultural sector,

\footnotetext{
1 This information is taken from a speech titled "EMERGING OPPORTUNITIES IN AGRICULTURE IN LAGOS STATE" by Prince Gbolahan Lawal, the Honourable Commissioner for Agriculture \& Cooperatives, Lagos State at the AGRICULTURE THE NEW FRONTIER: Access To Information Within the Agriculture Sector Organised by the Skills Enhancement Centre (SENCE) 30th March 2012.
} 
putting Lagos in danger of being engulfed in food crisis. As rice is an important staple food for millions of "Lagosians" and Nigerians [17], the perception is that food security can be assured in Lagos State through the Expansion of Rice for Job Initiative Programme. The programme has been able to increase cultivable land with the long grain improved rice variety. This is because farmers are being supported with various inputs ranging from improved seeds, fertilizer, agro chemicals and herbicides to increase productivity.

Accurate measurement of food security is essential for effective research and focused policies. Accurate measurement is important for targeting food and economic aid; evaluating health and developing programmes and informing government policy across many sectors [18]. Measurement will allow the understanding of a progress of a situation, whether food insecurity is chronic or transitory [12]. It will show the proportion of food insecure and their location.

Small-scale rice farmers in Nigeria can play a key role in ending food insecurity, stimulate economic growth, and reduce poverty and unemployment if they are included in the value chain. Reference [19] recommends competitiveness of local rice in Nigeria. Small farmers produce an estimated $80 \%$ of the food in Africa annually, but most of them lack the capacities to sell their crops in commercial markets [20]. Nigeria continues to import more food each year than it exports. An estimated $60 \%$ of the world's uncultivated farmable land is in Africa, yet many people still don't have enough to eat [20]. Small farmers in Nigeria are in this category. From the foregoing, it is important to find answers to the following questions. What is the food security status of the rice farm households in the study area? What factors determine the food security status of rice farm households in the study area? What are the constraints to rice production in the study area? Answers to these questions are important for a food secured future.

Food security policies in Nigeria are centered on rural development, access to farm inputs, political stability, poverty reduction and peasant farmers' education [36]. In view of the past studies that revealed the importance of education [28, 33], family size [33, 34], farm size [35] and income [35] on food security, the following null hypotheses were tested in this study. Education has no significant effect on household food security. Family size has no significant effect on household food security. Farm size has no significant effect on household food security. Household income has no significant effect on household food security.

\section{Research Methods}

\subsection{The Study Area}

The study area is Badagry Local Government Area in Lagos State Nigeria. The ancient town of Badagry is located in Southwestern part of Nigerian, border with Benin Republic. It is located precisely between latitude $6.5^{\circ} \mathrm{N}$ of the
Equator and longitude $3.25^{\circ} \mathrm{E}$ of the Greenwich Meridian. It is bounded on the West by Porto Novo and Weme; on the North by Ilogbo, Ipokia; on the South by the Osa lagoon and the Atlantic ocean and on the East by the Awori settlements of Ojo and Lagos [21].

Badagry (traditionally Gbagle) is a coastal town and Local Government Area in Lagos State, Nigeria. It is situated between metropolitan Lagos, and the border with Benin at Seme. As of preliminary 2006 census results, the municipality had a population of 241,093 and an area of $170 \mathrm{sq} \mathrm{m}$ or $441 \mathrm{~km}^{2}$ [22]. It was founded in the early 15 th century on a lagoon off the Gulf of Guinea. Its protected harbor led to the town becoming a key port in the export of slaves to the Americans. From the 1840's following the suppression of the slave trade, Badagry declined significantly, but became a major site for Christian mission work; it was annexed by the United Kingdom and incorporated into the Lagos colony in 1863 and became a part of Nigeria in 1901 [22].

Badagry subsists largely on fishing and agriculture, and maintains a small museum of slavery. The types of crop grown in Badagry include tree crops like coconut, oil palm etc. while food crops like maize, yam, cocoyam, rice are also planted. The residents are also involved in mat making and some are traders because of the presence of border. The type of soil in the study area is sandy loam which makes it suitable for farming.

\subsection{Sampling Method}

Primary data were collected through the use of structured questionnaires which were personally administered to the beneficiaries (household heads) of the Expansion of Rice for Job Initiative in the study area. We collected information on the socio-economic characteristics such as age, sex, education, household size, household income, year of farm experience, farm inputs and output to fulfill the objectives of the study. Simple random technique was used to select the required sample size for the study. It involves using balloting method in choosing the required number of beneficiaries (120) of the Expansion of Rice for Job Initiative programme from the list of the current 180 beneficiaries of the empowerment programme. The list of the beneficiaries was obtained from the programme office in Badagry. All the farmers were not available for interview, thus the basis for random sampling of the beneficiaries who are concentrated in Badagry. Farm household heads were visited and interviewed.

\subsection{Analytical Techniques}

FAO [9] admitted the fact that there is no perfect single measure that can capture all the dimensions of food insecurity. Thus, United State Department of Agriculture (USDA) Household Food Security Survey Module (HFSSM) method was used to assess the food security status of the households. This method is preferred because of the 
strengths shown in literature. It is an experienced-based food insecurity assessment method. Bashir and Schilizzi [23] asserted that dietary intake method and food insecurity experienced-based measurement scales are the two most commonly used methods. Logit model was employed to examine the determinants of food security.

\subsubsection{Measuring Household Food Security}

Guides to measuring household food security revised 2000 and Economic Research Service, USDA [24] procedures were followed. The HFSSM formally referred to as Food Security Core Module (FSCM) contains 18 items for household with children and 10 items for household without children. Thus, the complete response requires either 18 or 10 valid answers. The standard USDA food security scale uses 12 month reference period but the questionnaire items may be modified to capture other shorter reference periods [24]. The 30 days scale developed and reported for the 1995 Current Population Survey (CPS) data used 5 or more days within the past 30 days as the criterion for coding affirmative responses on these indicators as against 1 or 2 months used in the case of 12 month reference period. The 30 -day reference period was used in this study because of lack of food record keeping among households in Nigeria and to reduce problems relating to memory recall.

Continuous and categorical methods are often used. The continuous method involves classifying household on a scale range [25]:

For reporting purposes, USDA describes households with high or marginal food security as food secure and those with low or very low food security as food insecure. It should be noted that the two methods give the same result as households with score value ranges between $0-2$ are classified as food secure while those with score range of 3-18 or 3-10 (for households without children) are classified as food insecure. Therefore, households were categorized into food secure or food insecure using the continuous method. This category was used for logit analysis.

\subsubsection{Determinants of Food Security}

Following [26] Logit model is specified as follows. Let $\left(\mathrm{Y}_{\mathrm{i}}, \mathrm{X}_{\mathrm{i}}\right), \ldots,\left(\mathrm{Y}_{\mathrm{n}}, \mathrm{X}_{\mathrm{n}}\right)$ be a random sample from the conditional Logit distribution:

The probability of being food secure is given by:

$$
P_{i}\left[Y_{j}=1 / X_{j}\right]=\frac{1}{1+\exp \left(-\beta_{o}-\beta_{j} X_{j}\right)}
$$

The probability of being food insecure is given by:

$$
\begin{gathered}
\left.\left.P_{i} \mid Y_{j}=0 / X_{j}\right\rfloor=1-P_{i} \mid Y_{i}=1 / X_{j}\right\rfloor \\
=\frac{\exp \left(-\beta_{o}-\beta_{j} X_{j}\right)}{1+\exp \left(-\beta_{o}-\beta_{j} X_{j}\right)}
\end{gathered}
$$

This model is called a Logit model because:

$$
\left.P_{i} \mid Y_{j}=1 / X_{j}\right\rfloor=F\left(\beta_{o}+\beta_{j} X_{j}\right)
$$

Where:

$$
F(Z)=\frac{1}{1+\exp \left(-Z_{j}\right)}
$$

Is the distribution function of the logistic (Logit) model.

The ratio of probability of being food secure to food insecure is given as:

$$
\frac{\left.P_{i} \mid Y_{j}=1 / X_{j}\right\rfloor}{1-P_{i}\left[Y_{j}=1 / X_{j}\right]}=\frac{1}{\exp ^{-Z j}}=e^{Z j}
$$

Where: $Z_{j}=\beta_{o}+\beta_{j} X_{j}$

Therefore:

$$
\log _{e} \frac{P_{i}\left[Y_{j}=1 / X_{j}\right\rfloor}{1-P_{i}\left[Y_{j}=1 / X_{j}\right]}=Z_{j}
$$

Where the $X_{j}$ 's are the explanatory variables and $\beta_{\mathrm{o}}$ and $\beta_{\mathrm{i}}$ are unknown parameters to be estimated. Ordinary Least Squares technique is not appropriate for the estimation because the dependent variable $\left(\mathrm{Y}_{\mathrm{i}}\right)$ takes the value of 1 if the household is food secure and 0 if otherwise. Thus the probabilities of household being food secure $\left(\mathrm{P}_{\mathrm{i}}\right)$ was estimated from the $Z_{\mathrm{j}}$ through the logistic regression as:

$$
\begin{gathered}
Z_{j}=\beta_{o}+\beta_{1} X_{1}+\beta_{2} X_{2}+\beta_{3} X_{3}+\beta_{4} X_{4}+\beta_{5} X_{5}+\beta_{6} X_{6}+ \\
\beta_{7} X_{7}+\beta_{8} X_{8}+\beta_{9} X_{9}+u
\end{gathered}
$$

In these equations, $\mathrm{P}_{\mathrm{i}}$ is the probability that the household is food secure. $\mathrm{F}\left(Z_{i}\right)$ is the standard logistic cumulative function, $n$ is the number of explanatory variables, $Z_{i}$ is the unobservable level of stimulus for the ith household and $\mu_{\mathrm{i}}$ is random variable; $\mu_{\mathrm{i}}$ is normally distributed $\left(\mathrm{N}\left(0, \delta^{2}\right)\right.$.

Where:

$\mathrm{X}_{1}=$ Age of household head (years)

$\mathrm{X}_{2}=$ Primary occupation of household head (farming $=1$, otherwise $=0$ )

$\mathrm{X}_{3}=$ Marital status of household head (married $=1$, otherwise $=0$ )

$\mathrm{X}_{4}=$ Educational level of household head (no of years spent in school)

$\mathrm{X}_{5}=$ Household size (number of individuals)

$\mathrm{X}_{6}=$ Dependency ratio $(\%)$

$\mathrm{X}_{7}=$ Farm size (hectares)

$\mathrm{X}_{8}=$ Years of farming experience of household head

$\mathrm{X}_{9}=$ Household income (Naira)

$\beta_{0}=$ Constant

$\beta_{1}-\beta_{9}=$ coefficients of explanatory variables

$\mathrm{u}=$ Error term

\section{Results and Discussion}

\subsection{Rice Farm Household Heads' Socio-economic Characteristics}


The result in Table 1 shows that majority (46.7\%) of the respondents fall between 30 and 39 years of age. With an average age of 37 years, the respondents are expected to be very active on the farm and more responsive to agricultural innovation. This could also lead to a boost in agricultural activities. Reference [27] recognizes that young people are more likely to be energetic and have the capacity to use innovation.. The finding also shows that majority $(75.8 \%)$ of the rice farm households are males. This result agrees with reference [1] that majority of rice farmers in Nigeria are male. This implies that men dominate rice production in the study area probably because of the stressful nature of farming. This however, does not mean that females are not involved in farming. Females in this study area are helpers or suppliers of labour in light farm operations such as harvesting, winnowing and processing of farm produce.

Marital status had been shown to be an important variable in farming. Majority $(76.7 \%)$ of the respondents were married. The implication is that they undergo the programme to increase household income in order to meet household needs. Majority $(82.5 \%)$ of the respondents had formal education (at least primary education). The average educational level of the farmers is 13 years. This is so because the programme is organized to empower residents of Lagos State. Therefore, literate individuals responded more positively to the programme. This may have effect on the resource allocation of the farmers.

Table 1. Socio-economic Variables of Rice Farm Household Heads

\begin{tabular}{|c|c|c|}
\hline Variables & Dominant Indicators & Mean \\
\hline Age & $46.7 \%$ aged between $30-39$ years & 37.1 years \\
\hline Gender & $75.8 \%$ male & \\
\hline Religion & $68.3 \%$ Christians & \\
\hline Marital status & $76.7 \%$ married & \\
\hline Education & $\begin{array}{c}82.5 \% \text { had at least primary } \\
\text { education }\end{array}$ & 13.0 years \\
\hline $\begin{array}{l}\text { Primary } \\
\text { occupation }\end{array}$ & $62.5 \%$ are farming & \\
\hline Household size & $\begin{array}{c}65.0 \% \text { had between } 5 \text { and } 9 \\
\text { persons }\end{array}$ & 7.0 persons \\
\hline Farm size & $\begin{array}{c}68.3 \% \text { had between } 3 \text { and } 9 \\
\text { hectares }\end{array}$ & 4.76 hectares \\
\hline $\begin{array}{l}\text { Farming } \\
\text { experience }\end{array}$ & $\begin{array}{c}66.7 \% \text { had between } 5 \text { and } 20 \\
\text { years }\end{array}$ & 14.87 years \\
\hline $\begin{array}{l}\text { Household } \\
\text { Income }\end{array}$ & $\begin{array}{l}61.7 \% \text { had between } \\
\$ 200,000-\$ 399,999\end{array}$ & N329,166.67 \\
\hline
\end{tabular}

Source: Authors' computation from survey data, 2013

As shown in Table 1, majority (62.5\%) of the respondents engaged primarily in farming, while the other occupations like trading, artisanship, transporting and civil service occupied about $27.5 \%$. Also, majority $(65.0 \%)$ of the respondents had between 5-9 household members. The household size is fairly large. With an average of 7 members, there is likely pressure on household income. This means more household members may be available to assist the household head in rice farming operations (planting, weeding, harvesting, processing). The farm size is a factor that determines the scale of production. The result indicates that majority $(68.3 \%)$ of the respondent cultivated between 3 and 9 hectares. The mean farm size is 4.76 hectares. This shows that the respondents in the study area operate small farm size which demonstrates that output may be meagre with low income.

The finding also shows that majority (66.7\%) of the rice farm households had between 1 and 20 years of experience in rice farming. This is so because majority of the respondents are not primarily rice farmers. They get involved in rice production because of the empowerment programme. It is also revealed that majority $(61.7 \%)$ of the respondents earned between $\$ 200,000$ - $\$ 399,999$ per annum. The mean farm household income was estimated at $\$ 329,166.67$. This implies that majority of the respondent earned moderate income which is due to their small farm size resulted from moderate output.

\subsection{Food Security Status of the Rice Farm Households}

The description of food security status of the rice farm households based on the degree of severity is presented in Table 2 . The result shows that $47.5 \%$ of the respondents are food secure which implies that these households have access to sufficient, safe and nutritious food for an active and healthy life. Majority $(52.5 \%)$ of the households are food insecure. These households are classified based on the degree of severity. Approximately $26 \%$ of the food insecure households are food insecure without hunger implying that food access, food quality and quantity have been compromised which may be due to limited financial resources. Also, 23.3\% of the food insecure households are food insecure with moderate hunger while $3.3 \%$ are food insecure with severe hunger which means there is an indication of reduced food intake and disrupted eating patterns among adults and children.

Table 2. Food Security of the Rural Households Based on Degree of Severity

\begin{tabular}{ccc}
\hline Degree of Severity & Frequency & Percentage \\
\hline Food secure & & \\
Food insecure without & 57 & 47.5 \\
hunger & 31 & 25.8 \\
Food insecure with & 28 & 23.3 \\
moderate hunger & 4 & 3.3 \\
Food insecure with severe & & \\
hunger & 120 & 100 \\
Total &
\end{tabular}

Source: Authors' computation from the survey data, 2013

The proportion of food insecure households is relatively low when compared with the results from similar studies in Nigeria. For instance, reference [28] reported $70 \%$, reference [29] reported $69.9 \%$, reference [30] reported $68.80 \%$, reference [31] reported $63.3 \%$ while Ibok [32] reported $87.56 \%$. The findings confirm that many rice farm households are confronted with inadequate food quality, insufficient food quantity and small proportion may be acquiring food through socially unacceptable means. The implication of food insecurity to the household is that it leads 
to stunting and chronic nutritional deficiencies in the household which leads to high rate of diseases and illnesses.

\subsection{Determinants of Food Security among Rice Farm Households}

The factors that determine the food security status of rice farm households were examined and the results are presented in Table 3. The Chi-square value of 164.21 is significant at $1 \%$, implying that the Logit model was well fitted. Marital status is negatively significant at $1 \%$ implying married households have the likelihood of high food insecurity incidence than the single households. Educational level is positively significant at $1 \%$ which implies that a unit increase in the number of year spent in school increases the probability of household being food secure. The odds ratio of 1.02 implies that there is a 50/50 chance that households would be food secure with a small change in year of education of the household head. This conforms to findings of $[28,33]$ who reported that educational status of the household head tends to influence food security. Household head education largely contribute to working efficiency, competency, diversifying income, adopting innovative technologies and becoming visionary in creating conducive environment. Also, high education status of household head assists in ability of thinking and acting.

Household size is negatively significant at $1 \%$ which implies that one unit increase in the number of household increases the probability of household food insecurity. The odds ratio of -1.05 mean there is a 50/50 chance that household would be food secure with a small increase in household size. Large family size may lead to a reduction in food and nutrient intake which invariably causes food insecurity. High family size put more pressure on household income especially when the household income remains the same. This agrees with $[33,34]$ findings that high household size increases the probability of household food insecurity.

Farm size is positively significant at $1 \%$ which implies that one point increase in the hectare of land cultivated increases the probability of the household food security. The odds ratio (1.07) for farm size implies that there is a $50 / 50$ chance that households would be food secure if the farm size increases by small unit. This result is corroborated by [35] that increase in farm size increases the probability of food security. An increase in hectares of land cultivated may increase productivity which results in higher income to meet household needs. Household income is positively significant at $1 \%$ which implies that a unit increase in household income increases the probability of being food secure. The odds ratio attest to the fact that household has $50 / 50$ chance of being food secure or otherwise if the household income increases by small unit. Household access to food is very influenced by household income. According to [35], household income is used as an indicator for household food security because income is important for household food access.

Table 3. Determinants of Food Security among Rice Farm Households

\begin{tabular}{|c|c|c|c|c|}
\hline $\begin{array}{c}\text { Socio-economic } \\
\text { Variables }\end{array}$ & Co-efficient & $\begin{array}{c}\text { Standard } \\
\text { Error }\end{array}$ & T-value & $\begin{array}{l}\text { Odds } \\
\text { Ratio }\end{array}$ \\
\hline Constant & 0.5969 & 0.2547 & 2.34 & - \\
\hline Age & -0.0051 & 0.0065 & -.78 & -1.0051 \\
\hline Occupation & -0.00267 & 0.0180 & -1.48 & -1.027 \\
\hline Marital Status & $-0.1467 * * *$ & 0.0451 & -3.25 & -1.158 \\
\hline $\begin{array}{l}\text { Educational } \\
\text { Level }\end{array}$ & $0.0225^{* * *}$ & 0.0056 & 4.01 & 1.0228 \\
\hline Household Size & $-0.0502 * * *$ & 0.0160 & -3.13 & -0.0515 \\
\hline $\begin{array}{l}\text { Dependency } \\
\text { ratio }\end{array}$ & 0.1115 & 0.2399 & 0.47 & 1.1180 \\
\hline Farm Size & $0.0687 * * *$ & 0.0198 & 3.47 & 1.0711 \\
\hline $\begin{array}{c}\text { Farm } \\
\text { Experience }\end{array}$ & -0.0038 & 0.0049 & -0.78 & -1.0038 \\
\hline $\begin{array}{l}\text { Household } \\
\text { Income }\end{array}$ & $0.00001 * * *$ & 0.0000 & 3.76 & 1.0000 \\
\hline $\begin{array}{l}\text { Log likelihood } \\
\text { function }\end{array}$ & $-0.1331 \mathrm{E}^{-11}$ & & & \\
\hline $\begin{array}{c}\text { Restricted log } \\
\text { likelihood }\end{array}$ & -82.1078 & & & \\
\hline Chi-squared & $164.2156^{* * *}$ & & & \\
\hline
\end{tabular}

Source: Authors' Computation from the survey data, 2013

*** Significant at $1 \%, * *$ Significant at $5 \%$, $*$ Significant at $10 \%$

\subsection{Constraints to Rice Production}

The production constraints confronting the rice farmers are ranked and presented in Table 4. Although, government provided them with irrigation facilities but these were not sufficient for the expanses of land cultivated by the farmers thereby making them having lands not covered by the irrigation facilities. Many of the farmers therefore, rely on rainfall. Lack of access to technical knowhow is ranked second. This is because most of the respondents are not primarily rice farmers but took the advantage of the empowerment programme. Necessary technical knowledge is required for efficient utilization of available resources and combination of various inputs for maximum output. Visitation by extension officers is ranked third. This shows the inadequacy of extension services in Lagos in particular and Nigeria in general. This inadequacy affects farmers' technical knowhow because extension agents should assist the dissemination of new practices, ideas, positive attitude and technical knowledge to be adopted by the farmers. 
Table 4. Ranked Constraints to Rice Production among the Beneficiaries

\begin{tabular}{cccccccccccc}
\hline Constraints & \multicolumn{3}{c}{ Low } & \multicolumn{3}{c}{ Moderate } & & High & & $\begin{array}{c}\text { Final } \\
\text { Weight }\end{array}$ & Rank \\
\hline & Frq. & Wight & Val & Frq. & Wight & Val. & Frq. & Wight. & Val. & & \\
Access to Land & 59 & 1 & 59 & 37 & 2 & 74 & 24 & 3 & 72 & 205 & 5 \\
Low Technical & & & & & & & & & & & \\
knowledge & 2 & 1 & 2 & 92 & 2 & 184 & 26 & 3 & 78 & 264 & 2 \\
Inadequate Rainfall & 1 & 1 & 1 & 15 & 2 & 30 & 104 & 3 & 312 & 343 & 1 \\
Access to Facilities & 24 & 1 & 24 & 94 & 2 & 188 & 2 & 3 & 6 & 218 & 4 \\
Access to Fertilizer & 88 & 1 & 88 & 24 & 2 & 48 & 8 & 3 & 24 & 160 & 6 \\
Low Extension Visits & 20 & 1 & 20 & 96 & 2 & 192 & 4 & 3 & 12 & 224 & 3 \\
Access to Credit & 95 & 1 & 95 & 15 & 2 & 30 & 10 & 3 & 30 & 155 & 7 \\
\hline
\end{tabular}

Source: Authors' Computation from the survey data, 2013

Lack of access to facilities is ranked fourth on the problem scale because facilities were installed but not servicing the entire farm and not functioning properly because of improper monitoring, maintenance and large expanses of land cultivated. Also, lack of access to land is ranked fifth. This is not really a problem to rice farmers because land is given free to the beneficiaries of the programme. Land is part of the initiative for the empowerment programme. Lack of access to fertilizer is ranked sixth because fertilizers and other inputs or incentives are supplied by the government. Lack of access to credit facilities is last in the ranking because the programme is cooperative in nature and loans are given to beneficiaries by Government. The findings revealed that all the problems examined are well attended to and addressed during the formative years of the programme. As year progresses, lapses start occurring and gave rise to these inadequacies which also led to quitting of the programme by some of the beneficiaries. The membership of the programme which rises initially is reducing every day. This may threaten household food security.

\section{Conclusions}

There is high incidence of food insecurity among the rice farm households though lower than average of $70 \%$ reported by many studies in Nigeria. Food insecurity is influenced by small farm size, low farm income, large family size, low involvement in other occupation, inadequate agricultural extension services and non-consumption of high nutritional food. Educational level, household size, farm size and household income determine food security as hypothesized. Inadequate rainfall, lack of technical knowledge and low extension services constrained rice production in the study area. Large household size reduces the consumption of nutritious food; low extension information reduces the adoption of new innovation and inadequate technical know-how reduces efficiency. These reduce income and increase incidence of food insecurity. The need to educate farm households on how to control family size and adequate training on improved farm techniques is necessary.

The following policy options are recommended: First, there is the need to educate household heads on the nutritional importance of many food items. This is necessary for the food insecure households to be able to make appropriate choices on matters of food consumption. Second, family size needs to be controlled to ensure food security among households. Third, more irrigation facilities should be installed and farm size expansion is recommended. This will increase the productivity of the beneficiaries of the programme because reliance on rainfall elongates farming period due to unstable rainfall pattern. Increased productivity would guarantee high income. Fourth, diversification of household income will ensure regular incomes for the households. Fifth, improvement in extension services is important. This will afford the farmers the opportunity to efficiently allocate farm resources, understand the modern agricultural production techniques and ease access to improved rice production technologies. Lastly, adequate and improved production inputs and incentives should be provided to farmers as a way of keeping them in farming.

\section{REFERENCES}

[1] Y. L. Idrisa,, M. M. Gwary and H. Shehu, H. (2008). Analysis of Food Security Status Among Farming Households in Jere Local Government Area of Borno State, Nigeria. Journal of Tropical Agriculture, Food, Environment and Extension. 7 (3): 199-205.

[2] FAO (2006a): The State of Food Insecurity in the World 2006: Eradicating World Hunger Taking Stock Ten Years after the World Food Summit. Food and Agricultural Organisation of the United Nations, Rome.

[3] O. Erenstein, S. O. Lancon, T. Akande, S. O. Titilola, G. Akpokodje and O. O. Ogundele (2003). The Nigerian Rice Economy in a Competitive World: Constraints, Opportunities and Strategic Choices. Rice production Systems in Nigeria: A survey. West Africa Rice Development Association (WARDA), Abidjan, Côte d'Ivoire.

[4] FAO (2008). Hunger on the Rise. Food and Agricultural Organisation of the United Nations, Rome, 18 September, 2008.

[5] FAO (2010). The State of Food Insecurity in the World: Addressing Food Insecurity in Protracted Crises. Food and Agricultural Organisation of the United Nations, Rome.

[6] M. K. Bashir, S. Schilizzi and R. Pandit (2012). The 
106 Expansion of Rice for Job Initiative Programme: Implications for Household Food Security in Lagos State Nigeria

Determinants of Rural Household Food Security for Landless Households of the Punjab, Pakistan. Working Paper 1208, School of Agricultural and Resource Economics, University of Western Australia, Crawley, Australia.

[7] T. G. Bimerew and F. Beyene (2014). Factors Influencing Rural Household Food Insecurity: The Case of Babile District, East Hararghe Zone, Ethiopia. Journal of Development and Agricultural Economics. 6(4): 149-158.

[8] FAO (2006b). Food Security Policy Brief, June 2006, Issue 2. Food and Agricultural Organisation of the United Nations, Rome.

[9] FAO (2002). Food Insecurity: When People must live with hunger and fear starvation. The State of Food Insecurity in the World. Food and Agricultural Organization of the United Nations, Rome.

[10] FAO (1996). World Food Summit: Rome Declaration on World Food Security. Food and Agricultural Organisation of the United Nations, Rome.

[11] P. Pinstrup-Andersen (2009). Food Security: Definition and Measurement. Food Security. 1: 5-7.

[12] P. Webb, J. Coates, E. A. Frongillo, B. L. Rogers, A. Swindale and P. Bilinsky (2006). Measuring Household Food Insecurty: Why It's So Important and Yet So Difficult to Do. Journal of Nutrition. Vol. 136, 1404S-1408S.

[13] FAOSTAT (2014). Country Profile, Nigeria. Available on http://faostat.fao.org/CountryProfiles/Country_Profile/Direct .aspx?lang=en\&area $=159$. Accessed on 05/07/2014

[14] O. I. Y. Ajani (2005). Determinants of Food Security of Low Income Households in the University of Ibadan. Journals of Economics and Rural Development. Vol. 14, No. 2,: 91-99.

[15] NPC (2001). National Policy on Food and Nutrition in Nigeria. National Planning Commission, Abuja.

[16] J. Chikaire, F. N. Nnadi, C. D. Nnadi and N. O. Anyoha (2011). Addressing the Needs of Rural Women Farmers to Achieve Food Security in Rivers State, Nigeria. Researcher Vol. 3, No. 10, 19-25.

[17] T. Akande (2003). The Rice Sector in Nigeria. United Nation Crop Project (UNCP). Country Agricultural Project on Trade Liberalization in Agricultural Sector and the Environment. Geneva.

[18] A. D. Jones, F. M. Ngure, G. Pelto and S. L. Young (2013). What Are We Assessing When We Measure Food Security? A Compendium and Review of Current Metrics. Advance in Nutrition Vol. 4, 481-505.

[19] S. Ajijola, J. M. Usman, O. A. Egbetokun, J. Akoun and C. S. Osalusi (2012). Appraisal of Rice Production in Nigeria: A Case Study of North Central States of Nigeria. Journal of Stored Products and Postharvest Research. Vol. 3, No. 9, 133-136.

[20] J. Lazuta, (2014). African Small Farmers Could be Key in Ending Food Insecurity. Voice of America. July 30, 2014. Accessed from www.voanews.com/content/African-small-farmers-could-bekey-toending-food-insecurity/1968271.html on 03/08/2014.

[21] V. S. Akran (2001). Lagos Historical Review. Vol. 1, 33-44.

[22] NPC (2006). Nigeria Population Census. 2006 . National
Population Census (NPC).

[23] M. K. Bashir, and S. Schilizzi (2012). Measuring Food Security: Definitional Sensitivity and Implications. Contributed Paper Prepared for Presentation at the 56th Australian Agricultural and Resource Economics Society (AARES) Annual Conference, Fremantle, Western Australian, February 7-10, 2012.

[24] USDA, (2012). U.S Adult Household Food Security Survey Module: Three Stage Design, With Screener. Economics Research Service, USDA. September 2012. 1-12.

[25] G. Bickel, M. Nord, C. Price, W. Hamilton and J. Cook (2000) . Measuring Food Security in the United States. Guide to Measuring Household Food Security Revised 2000. United States Department of Agriculture (USDA), Food and Nutrition Service. 1-82.

[26] H. J. Bierens (2008). The Logit Model: Estimation, Testing and Interpretation. Lecture Notes. October 25, 2008.

[27] A. C. Anyanwu, A. E. Agwu and A. P. Musa (2001). Adoption of Gender Specific Innovation by Women in State, Journal of Agricultural Extension. Vol. 5, 64-72.

[28] R. A. Sanusi, C. A. Badejo and B. O. Yusuf (2006). Measuring Household Food Insecurity in Selected Local Government Areas of Lagos and Ibadan, Nigeria. Pak J Nutr Vol. 5, 62-67.

[29] O. R. Adeniji and O. A. Ojo (2013). Food security status of Rural Farming Households in Iwo, Ayedire and Ayedaade Local Government Areas of Osun State, South-Western Nigeria. African Journal of Food, Agriculture, Nutrition and Development.. Vol. 13, No. 5, 8209-8223.

[30] O. B. Akarue and O. T. Bakporhe (2013). Food Insecurity and its Determinant in Rural Households in Ugbelli North Local Government Area of Delta state, Nigeria. International Journal of Innovative Agriculture and Biology Research. Vol. 1, No.2, 20-30.

[31] G. T. Ahungwa, J. C. Umeh and B. G. Muktar (2013). Empirical Analysis of Food Security Status of Farming Households in Benue state, Nigeria. IOSR Journal of Agriculture and Veterinary Science. Vol. 6, No. 1, 57-62.

[32] O. Ibok (2014). Analysis of Food Insecurity Status of Urban Food Crop Farming Households in Cross River state, Nigeria: A USDA Approach. Journal of Agricultural Science. Vol. 6, No. 2, 132-141.

[33] G. G. Girma (2012): Determinants of Food Insecurity among Households in Addis Ababa City, Ethiopia. Interdisciplinary description of complex systems Vol. 10, No. 2, 159-173.

[34] M. Christine, B. S. Olson, E. A. Rauschenbach J. Frongillo and A. Kendall. Factors Contributing to Household Food Insecurity in a Rural Upstate New York County. Institute for Research on Poverty Discussion Paper No. 1107-96. Division of Nutritional Sciences, Cornell University, Ithaca, USA, 1996.

[35] O. A. Omotesho and A. Muhammad-Lawal (2010). Optimal food plan for rural households' food security in Kwara State, Nigeria: The goal programming approach. Journal of Agricultural Biotechnology and Sustainable Development. Vol. 2, No. 1, 007-014.

[36] A. W. Attah (2012). Food Security in Nigeria: The Role of Peasant Farmers in Nigeria. African Research Review. Vol. 6, No. 4, 173-190 